\title{
THE SOCIO-POLITICAL ATTITUDES OF THE DON COSSACKS IN THE FIRST HALF OF THE 1920s ${ }^{1}$
}

\author{
Olga V. Rvacheva \\ Russian Presidential Academy of National Economy and Public Administration (Volgograd Branch), \\ Volgograd, Russian Federation
}

\begin{abstract}
The study of socio-political attitudes of the Don Cossacks in the early 1920s is of large importance for understanding the socio-political processes in the south of Russia at that time. After the Soviet power was established in the Don region, relations of mutual distrust formed between the Cossacks and the new power. The Soviet authorities viewed the Cossacks as a potentially counter-revolutionary force, though actual economic collapse and repressions from the state authorities considerably undermined the counter-revolutionary enthusiasm and brought social apathy among the Cossacks. Generally the sociopolitical attitudes of the Don Cossacks in 19201922 can be described as follows. These were sporadic acts of disloyalty provoked primarily by the economic crisis and general social disruption in Cossack villages. By 1923 the situation had gradually changed. The economic growth contributed to a more positive attitude among Cossacks and peasants. The strengthening of the Soviet power, along with the policy of attention to peasants' and Cossacks' needs, made the Cossacks more loyal. They gradually got involved in the process of Soviet construction, took part in organization of the use of land, in elections to Soviet bodies, and so on. The article reveals the Don Cossacks' attitudes in 1920-1924 and determines their causes, characteristics and changes under various factors.
\end{abstract}

Key words: Don Cossacks, socio-political attitudes, Soviet period, attitude to authorities, attitude to party, Soviet construction, economic and political processes.

\section{СОЦИАЛЬНО-ПОЛИТИЧЕСКИЕ НАСТРОЕНИЯ ДОНСКОГО КАЗАЧЕСТВА В ПЕРВОЙ ПОЛОВИНЕ 1920-х ГОДОВ ${ }^{1}$}

\author{
Ольга Владимировна Рвачева \\ Волгоградский филиал Российской академии народного хозяйства и государственной службы, \\ г. Волгоград, Российская Федерация
}

Аннотация. Изучение общественно-политических настроений донского казачества в начале 1920-х гг. представляет большой интерес с точки зрения понимания социально-политических процессов, происходивших на юге России в данный исторический период. После окончания Гражданской войны и установления советской власти на территории Донской области между новой властью и казаками складываются отношения взаимного недоверия. Советско-партийное руководство рассматривало казаков как потенциально контрреволюционную силу, однако изучение настроений данной социальной группы позволяет говорить о сложном и неоднозначном отношении казачества к новой власти. Экономическая разруха в казачьих округах в
} 


\section{РЕГИОНОВЕДЕНИЕ}

послевоенный период, а также репрессии со стороны большевистского руководства существенно снизили контрреволюционный потенциал казачества, сформировали настроения социальной апатии. В целом социально-политический аспект общественных настроений донских казаков в 1920-1922 гг. можно характеризовать следующим образом. Это эпизодические проявления недовольства, связанные, прежде всего, с хозяйственной разрухой и общей социальной дезорганизацией жизни в станицах и хуторах, ситуативное политическое недовольство действиями власти. Затем в связи с постепенным восстановлением хозяйства и общей социально-политической и экономической стабилизацией на юге России, складывался более позитивный настрой казачье-крестьянской общественности в целом. Укрепление советской власти, наряду с изменением ее курса в отношении крестьянства и казачества, складывание политики «лицом к казачеству» приводило к формированию социально открытого поведения казаков. Население казачьих станиц и хуторов постепенно начинало принимать участие в советском строительстве, процессах землеустройства, выборах в Советы и т. д. В статье предпринята попытка выявить и проанализировать общественные настроения донского казачества в 1920-1924 гг., определить причины и характер этих настроений, а также влияние на них различных факторов.

Ключевые слова: донское казачество, социально-политические настроения, советский период, отношение к власти, отношение к партии, советское строительство, экономические и политические процессы.

В историческом контексте исследование общественных настроений является подчас весьма сложной задачей, связанной, на наш взгляд, прежде всего, с механизмами и формами фиксации этих настроений в конкретный исторический период и их научной верификацией. Исследование данного явления в советский период осложнено также тем, что официальная реакция населения на те или иные события в социально-экономической и политической сферах, отражавшаяся, например, на страницах печати, содержала значительный манипулятивный компонент со стороны власти и нередко имела расхождения с теми настроениями, которые проявлялись в обществе в неофициальных условиях. Нуждаясь, как и любой политический режим, в поддержке народа, выражаемой, в том числе через общественное мнение, советский режим постепенно нарабатывал и совершенствовал как формы мониторинга и анализа общественных настроений, так и механизмы воздействия на них.

Формирование и проявление общественных настроений казаков зависело от множества факторов, но было, на наш взгляд, несколько определяющих моментов, игравших ключевую роль в этих процессах в рассматриваемый период. Во-первых, казачество в начале 1920-х гг. представляло собой послевоенное сообщество, в котором были сломаны или изменены привычные хозяйственные и социальные связи, нормы поведения. По итогам Гражданской войны на юге России казачье население стало коллективным объектом политического насилия. Во-вторых, на общественные настроения казаков влияли серьезные людские потери, которые они понесли в годы Гражданской войны, а также сокращение населения (особенно мужского) в результате эмиграции после разгрома антибольшевистских сил на юге России в начале 1920 года. В-третьих, хозяйственная разруха, принявшая в ряде районов Донской области катастрофические размеры. И, наконец, в-четвертых, кардинальное изменение места и статуса рассматриваемой группы в новой общественной системе [2, с. 162]. Последнее имело отношение скорее к числу психологических факторов, но, тем не менее, многие социально-политические проявления настроений казачества прямо или косвенно содержали данный аспект.

Цель статьи - выявить и проанализировать социально-политические настроения донского казачества в 1920-1924 гг., то есть до того времени, когда под влиянием нового политического курса партии «лицом к деревне» взаимоотношения данной социальной группы и советско-партийного руководства начали постепенно изменяться, и казаки стали включаться в процессы советского строительства.

Рассматриваемый в статье период является сложным в изучении с точки зрения наличия источников, в которых фиксировались бы настроения казаков. Основными видами источников выступают документы партийных органов различного уровня, в которых, наряду с мероприятиями в отношении казачества, фиксировались и реакции этой группы населения в ответ на проводимую партией политику. В частности, такой группой источников, 
содержащих информацию о социально-политических настроениях и реакциях казаков в начале 1920-х гг. являются документы областных партийных конференций РКП(б). Поскольку в этот период партийная структура на местах еще только формировалась, претерпевая различные изменения, связанные как с внутренней перестройкой, так и с административно-территориальными изменениями Донской области, партийные документы содержат информацию по многим вопросам поверхностную, затрагивающую лишь самые насущные проблемы. К таковым, например, относились развитие бандитизма на казачьих территориях или преодоление хозяйственной разрухи. Тем не менее подробный анализ этих документов позволяет представить картину наиболее ярко проявляющихся социально-политических настроений донского казачества.

Альтернативным видом источников являются письма казаков к своим родственникам и знакомым в эмиграции, публикуемые в 1920-х гг. в эмигрантских казачьих журналах. Лишенные идеологического налета, они позволяют лучше понять настроения казачества, которые проявлялись в обычной бытовой обстановке как реакция на общую неустроенность жизни и послевоенную разруху, а также политическое давление власти.

По оценкам историков, начало 1920-х гг. было чрезвычайно сложным периодом: «Переход к миру происходил в условиях колоссальной разрухи, падения промышленного и сельскохозяйственного производства, в тяжелых последствиях братоубийственной гражданской войны, трагически разделивших казаков и крестьян, весь народ на два смертельно враждебных лагеря» [14, с. 11]. Настроения казачества в этот период обычно характеризуются как потенциально конфликтные, что было связано с репрессивной политикой в отношении казаков, а также продовольственными реквизициями, вызывавшими недовольство населения. По определению Я.А. Перехова: «Весь 1920 г. прошел в попытках успокоить казачество» $[14$, с. 20$]$.

Советско-партийные органы настороженно относились к казачеству, что отразилось на фиксации малейших изменений в настроениях данной группы. Во время работы Донских областных партийных конференций, проходив- ших в 1920 г., в выступлениях делегатов от округов значительное внимание уделялось характеристике настроений, поведения казачества, а также их хозяйственному и социальному положению. Делегаты отмечали, что «настроение казачества не такое уж хорошее, чтобы им можно было хвастаться» [21, л. 25]. Говорилось о том, что «настроение казачества остается прежним (антисоветским. - O. P.), и оно держит нос по ветру», а его хорошее отношение к советской власти, в данный момент проявляющееся в добровольной сдаче излишков хлеба, объясняется тем, что «этим казачество как бы откупается за свои прошлые грехи перед Советской властью» [21, л. 25].

Судя по представляемой делегатами конференции информации, больше всего их беспокоили контрреволюционные настроения в среде казачества, сила их проявлений, поддержка бандитизма, направления развития социального антагонизма и отношение к партии и власти. На первом месте по значимости для большевиков стояло обнаружение контрреволюционных настроений казаков, проявлявшихся, по их мнению, в бандитизме.

В 1920-1922 гг. в стране быстро нарастало протестное движение в форме вооруженных выступлений. В официальных документах такие выступления именовались бандитизмом или политическим бандитизмом. По оценкам исследователей, в 1920-1921 гг. Россия подошла к грани полномасштабной войны между государством и крестьянством [1, c. 119-129]. По данным Оперативного управления штаба войск внутренней службы РСФСР, к началу 1921 г. в стране было 71248 повстанцев, из них 19640 - на Северном Кавказе [1, c. 119-129].

В Донской области особенно актуальной связь контрреволюционных настроений казачества с выступлениями различных банд была для таких округов, как I Донской, Донецкий и Хоперский. Так, характеризуя состояние I Донского округа и настроения населения в нем, один из делегатов II Донской областной конференции говорил: «Наш округ пережил не одно восстание. Нас постоянно тревожили банды Свеколкина, Назарова и Северякина. Его не миновало махновское наступление, которое было два раза» [22, л. 65]. Делегат Донецкого округа отмечал: «Округ силь- 


\section{РЕГИОНОВЕДЕНИЕ}

но пострадал от махновцев... После агитации, которую вели махновцы, отношение к партии сильно изменилось... Не только середняки, но и бедняки... теперь после агитации махновцев окончательно оторвались от партии» [22, л. 58].

Комплексная информация, собранная органами ОГПУ по верхнедонским округам, создает впечатляющую картину распространенности контрреволюционных выступлений в казачьих районах. Согласно ей в Сталинградской области оказались охваченными такими выступлениями 20 районов ${ }^{2}$ [15]. Однако на поверку протестная активность казачьего населения Донской области была низкой. По мнению исследователей махновского движения, в донских округах крестьяне и казаки не восприняли махновскую армию в качестве освободительницы от большевиков и остались глухи к антибольшевистской агитации повстанцев $[4$, с. 454]. Причинами тому стали как поведение самих махновцев - кража лошадей, собранного по продразверстке хлеба что сразу заставило население занять пассивную, выжидательную позицию, так и память o «красном терроре» после восстания на Верхнем Дону [4, с. 448, 449, 455 и др.].

То же можно сказать и в отношении поддержки казаками вакулинского восстания. В декабре 1920 г. в слободе Михайловке Усть-Медведицкого округа произошел мятеж караульного батальона во главе с его командиром К.Т. Вакулиным [3, с. 529]. Как отмечал А.Н. Грищенко, восставшие поставили перед собой цель - побудить население Дона к поголовному восстанию, однако, как и в случае с махновским движением, население по большей части заняло выжидательную позицию, не доверяя руководителям повстанцев и справедливо полагая, что восстание носит локальный характер [3, с. 535, 538]. Другой известный исследователь вакулинского восстания В.Г. Ященко также отмечал, что казачье население не поддержало восставших, в результате чего они вынуждены были уйти в Заволжские степи [25, с. 37].

Подробный анализ причин и обстоятельств возникновения и развития вакулинского мятежа позволяет говорить, что казачьекрестьянское население донских округов, измученное продразверсткой, повстанцев все же поддерживало, но поддержка эта была в основном пассивной. Население соглашалось на смену власти, но вступать в ряды повстанцев отказывалось [3, с. 538].

Спецификой повстанческого движения на Дону являлось, прежде всего, то, что активной силой его нередко становились красные командиры и красноармейцы. К таковым относились и командир караульного батальона К.Т. Вакулин, и комбриг И.П. Колесов, и бывший комполка М.Г. Попов, и командир эскадрона караульного батальона Я.Е. Фомин и др. [25]. Население хуторов и станиц активного вооруженного сопротивления не оказывало.

Это подтверждалось и выступлениями делегатов из казачьих округов на партийных конференциях в Донской области в 1920 году. На них, в частности, говорилось о слабом проявлении контрреволюционных настроений и пассивной поддержке различного рода повстанцев, выражавшейся, прежде всего, в том, что местное население предоставляло повстанцам кров и пищу, но практически не участвовало в их деятельности. Так, делегат из Усть-Медведицкого округа в своем выступлении обращал внимание на то, что «контрреволюционные настроения наблюдаются, но выявля[ю]тся он[и] очень слабо. Трудно прицепиться и подавить реальные контрреволюционные явления... Когда здесь появился Махно, то местное население выразило свою преданность в защите Советской власти...» [22, л. 58].

Вместе с тем в округах, где политический бандитизм был особенно частым явлением, власти все же понимали, что такие банды являются потенциальным фактором обострения социально-политической обстановки на местах, и старались принять меры по недопущению развития негативных настроений. Так, в 1921 г. на одном из заседаний Хоперской окружной организации РКП(б) остро стоял вопрос о необходимости принятия превентивных мер «пресечения паразитического элемента, ввиду приближения бандитов». На заседании постановили: «Принимая во внимание, что на Хоперский округ надвигается банда Антонова, Колесникова и Варравина, а также вызывающее, в связи с этим поведение буржуазии, кулачества и спекулянтов, распространение контрреволюционной агитации, о воз- 
можной провокации, подбивающей бедноту на активные действия против Советской власти, пользуясь тяжелым продовольственным кризисом, объединенное заседание постановляет: “На все время угрожающего состояния для Хоперского округа, изъять заложников из паразитических элементов и активно принимавших участие в гражданской войне на стороне белых банд..."» [17, л. 67].

Один из наиболее сложных моментов в настроениях казачества в начале 1920-х гг. его отношения с новой властью. Следует учитывать не раз отмеченную исследователями многоаспектность восприятия этой власти казаками (как, впрочем, и крестьянами). Власть в глазах сельского населения разделялась на коммунистов, большевиков, руководителей местных советов, ревкомов. После окончания Гражданской войны между новой властью и казаками складываются отношения взаимного недоверия. Но наиболее негативным является отношение к коммунистам. Партработники из Верхнедонского округа Донской области на I-й Донской областной партийной конференции 1920 г. докладывали, что после активных действий Красной армии по подавлению антибольшевистского движения население было настолько запугано, что боялось даже самого слова «коммунист» и партработники старались его не упоминать [20, c. 14].

Однако в целом сообщения с мест в 1920 г. по поводу отношения донского казачества к власти были довольно противоречивы. С одной стороны, фиксировалась однозначно негативная реакция на представителей власти, а с другой стороны, делегаты демонстрировали оптимистичный взгляд на отношение казаков к партии и советской власти. На партийных конференциях 1920 г. делегаты из округов нередко характеризовали отношение казаков к партии как удовлетворительное, сочувственное. Чаще всего это означало, что со стороны населения нет активной поддержки большевиков, но и нет активного сопротивления их мероприятиям. Кроме того, установление и укрепление новой власти объективно вело к организации и развитию хозяйственной и социальной сфер жизни общества. И это благотворно отражалось на настроениях населе- ния, фиксируемых в выступлениях делегатов партконференций: «Казачество в настоящее время понимает, что только наша партия может дать ему спокойную жизнь, может дать возможность восстановить свои хозяйства» [21, л. 21].

Конечно, среди донского казачества были те, кто поддерживал большевиков. Например, 131 делегат от Донской области присутствовал на I Всероссийском съезде трудового казачества $[14$, с. 16]. По оценкам Р.Г. Тикиджьяна и А.П. Скорика, группа «убежденных сторонников большевиков» могла составлять примерно $30 \%$ [20, с. 46]. Однако более точной характеристикой восприятия донским казачеством большевистской власти, на наш взгляд, является негативность этого восприятия. Не стоит забывать, что организация новой власти происходит в ситуации проигрыша казаков как сторонников антибольшевиков в Гражданской войне. Новая власть - это не только власть большевиков, но и власть иногородних: налицо были не только политическое противостояние, но и социальное, и культурное. Советская власть и ее идейно-политические выразители - большевики - были непонятным и чуждым явлением для мира казаков. Впрочем, Р.Г. Тикиджьян и А.П. Скорик далее констатируют, что «основная масса донского казачества колебалась в своем выборе, нередко меняя позитивное ... отношение к большевистскому режиму на прямо противоположное» [20, с. 46].

На наш взгляд, в целом казачье население и Донская область воспринимались властью негативно. По мнению большевиков, Донская область представляла «неблагоприятную почву для нашей партии...», так как здесь мало сельскохозяйственного пролетариата и «нам приходится иметь дело с середняком и крестьянином и казаком» [24, л. 14].

Впрочем, разнообразие в оценках партийными работниками на местах социальных противоречий, связанных с сословным единством и стремлением большевиков расслоить казачество по классовому принципу, все же присутствовало. Так, с мест приходила информация как о том, что «...деления на кулаков и бедняков у нас не наблюдается, а есть деление на красных и белых», так и о том, что «раньше наблюдалось деление населения на 
казаков и иногородних, за последнее время заметно, что казацкие слои, как иногородние, так и казацкие одинаково враждебны к мероприятиям советской власти, а беднота казацк[ая] и крестьянство относится сочувственно» $[22$, л. 52, 66]. Отсутствие информации о сословной розни между иногородними и казаками (которой будут переполнены сводки с мест в 1925-1926 гг.), вероятно, являлось следствием хозяйственной разрухи послевоенного периода. Хозяйственные проблемы, проблемы выживания ненадолго сгладили сословную рознь.

Одна из наиболее часто встречающихся характеристик настроения казаков в этот период - это усталость от Гражданской войны. Этой усталостью и потерями, которые казачество понесло в Гражданскую войну, объяснялось его «смирение». При этом трактовка смирения казаков была различной. Так, часть делегатов I-й областной партийной конференции считала, что они всего лишь «притихли, боясь расправы», другая - что «казачество стало изменять свой старый курс» [21, л. 25, 28]. Один из наиболее критично настроенных докладчиков на этой конференции, прибывший из 2-го Донского округа, так резюмировал свое выступление: «Казачество устало и не способно к активной борьбе, скажем, на год, но казачество - прыткий дикий конь, и вожжи отпускать не следует» [21, л. 27]. Другие, более оптимистично настроенные, делегаты отмечали, что казачество стало ближе к советской власти и даже, по мнению делегата Хоперского округа, опередило крестьянство. Причиной же такого продвижения казачества стало то, что «казачество Хоперского округа в результате двухлетней войны совершенно опролетаризировалось. Целые хутора имеют иногда только 15 лошадей, одну-две пары волов и т. п. Это положение изменило их настроение в пользу Советской власти» [21, л. 29].

Информация с мест в период 19191921 гг. создает впечатление оглушенности и подавленности населения как войной, так и политикой новой власти. В сводках окружных комитетов РКП(б) за 1919-1920 гг. можно прочесть такую информацию. Из Хоперского округа: «В станицах, хуторах мужское население (почти 50 \%) бежало с белыми, остались старики, женщины и дети. На ми[тингах] присутствуют преимущественно женщины, мужское население боится показываться. Частая подводная повинность, реквизиция хлеба вызывают жалобы населения. Настроение по отношению к советской власти пассивное» $[19$, л. 8$]$; из Усть-Медведицкого округа: «Настроение в округе удовлетворительное... Пассивное настроение масс будет сломлено, если удастся прекратить явления, причиняющие населению явный ущерб в хозяйстве. ..» [19, л. 8], «контрреволюционное настроение наблюдается, но выявляется оно очень слабо»; из Донецкого округа: «До появления махновских банд настроение населения было удовлетворительно...» [21, л. 31, 32 и др.].

Восстановление хозяйства, разрушенного Гражданской войной, и экономические проблемы, вызываемые различного рода реквизициями и продразверсткой, были наиболее актуальны для всего населения Донской области. Именно они являлись наиболее сильными факторами, формировавшими настроения населения. По мере ухудшения хозяйственного состояния казачье-крестьянских хозяйств, что было связано в 1920 г. в первую очередь с политикой реквизиций, проводимых различными представителями новой власти, начинает накаляться и социально-политическая обстановка. Это признавалось и сотрудниками партийных органов. В качестве негативных явлений, причиняющих значительный ущерб казачье-крестьянским хозяйствам, отмечались, например: «бессистемная подводная повинность, доходящая до того, что после 2-х месяцев скитаний владельцы бросают своих волов и лошадей и возвращаются домой с одним кнутом», «бесчинства агентов армейских продовольственных комиссий, работающих по разным инструкциям, берущих продовольствие по разным ценам, забирающих сверх излишков и грубое отношение их...» $[19$, л. 8].

Экономический фактор был важнейшим, поскольку определял социальную динамику в России в начале 1920-х годов. Население ряда территорий, оказавшись в силу объективных и субъективных причин на грани выживания, очень чутко реагировало на малейшее ухудшение или улучшение своего хозяйства. Не только на казачьих территориях, но и в других районах страны обострение продовольствен- 
ной ситуации, вызванное как неблагоприятными погодными условиями, так и политикой государства по реквизиции продовольствия у крестьян, определяло социальное поведение сельского населения. Например, вспышки социальной агрессии на почве недовольства населения реквизициями фиксировались в районах среднего Поволжья, и в сводках партийных органов отмечалось, что в уездах развит бандитизм [23, с. 222-223]. Массовая агрессия сельского населения нередко провоцировалась беспределом чекистов и продотрядовцев, а характер протестных действий принимал форму самосуда [23, с. 222].

На казачьих территориях, о чем упоминалось выше, хозяйство было серьезно разорено Гражданской войной; как отмечали сами большевики: «Гражданская война, длившаяся почти три года здесь на Дону, больно ударила по экономической мощи казачества, поставив большой слой его в разряд неимущих и малоимущих....» [18, л. 36]. На территориях Верхнего Дона, в Хоперском, Усть-Медведицком, 2-м Донском и Верхнедонском округах ситуация была особенно тяжелой, так как в период Гражданской войны фронт здесь проходил несколько раз. В результате многие хутора и станицы пришли в полный хозяйственный упадок, а в совокупности с проводимыми реквизиционными мероприятиями продразверстки к концу 1920 г. это дестабилизировало обстановку в названных округах.

Существующую разницу положения верхнедонских и нижнедонских округов отмечали и сами представители власти. Из выступления Кинуидзе на II-й Областной Донской партийной конференции: «Всем известно, что есть огромная разница между северной и южной частями Донской области. Для Севера годятся одни методы работы, для Юга другие... Северная часть имеет другой состав (середняцкий), а в Южной есть помещики, и там нет элемента, который можно бы расслаивать... По-моему необходимо... учесть особенную разоренность Северной части и бросить туда экономический аппарат, который бы дал возможность наладить там коллективный труд...» [22, л. 82].

О том, насколько тяжелым было разорение населения в северных округах Донской области, свидетельствует состояние посевных площадей и рабочего скота. Посевные площади в этих районах, по сравнению с довоенным временем, сократились более чем в два раза. Так, в Хоперском округе, по данным Хоперского окружного комитета РКП(б), динамика изменений посевных площадей с 1913 г. по 1923 г. была следующей: 1913 г. - 595866 десятин; 1916 г. - 410023 десятин, 1923 г. - 236006 десятин [7, л. 67]. В 1916 г. на одно хозяйство во 2-м Донском округе приходилось 11,5 десятин посева, а в 1922 г. только 6,08. Средняя обеспеченность рабочим скотом в 1916 г. по 2-му Донскому округу составляла 3,48, а в 1922 г. 0,59 , то есть фактически свелась к нулю [8, л. 63]. То, что данная информация собиралась местными органами ОГПУ, дополнительно подтверждает важность экономического фактора при формировании настроений населения в рассматриваемый период.

Вместе с тем в определенном смысле сильное разорение казачьих территорий и хозяйственные потери способствовали «замирению» казаков. В своем докладе на II-й Донской областной партийной конференции представитель Донского областного комитета РКП(б) отмечал, что при встрече ударных назаровских групп стало ясно, что «казачья масса в достаточной степени разорилась вследствие гражданской войны и наконец поняла и узнала, что такое Советская власть. Не то было в 18 и 19 годах, когда каждый генерал и авантюрист встречал безотчетную поддержку казачьих масс» [22, л. 19]. Эта ситуация нашла свое отражение в характеристике, данной газетой «Известия»: «Если крестьянство пришло к советской власти через те положительные приобретения, которые оно получило от октябрьского переворота, то трудовое казачество приходит к советской власти через те потери, которые оно понесло в гражданской войне» [14, с. 21].

В этом смысле личные впечатления казаков от того времени позволяют лучше понять остроту ситуации. Из письма донского казака казакам-эмигрантам за границу: «Когда я пришел с Крыму, то у меня ничего не осталось из худобы (скотины. - O. P.) - только дом и кухня уцелели, а катухи спалили, а из инвентаря остались одни санки конные. Остальное-все под гребло забрали, и мне пришлось так страдать, что не дай Бог» [10, с. 29]. 
Данные по казачьим округам за $1922-$ 1924 гг. позволяют сделать вывод, что, по мере нормализации социально-политической и экономической ситуации, характер настроений казачества постепенно изменялся, становясь более позитивным. Хотя по-прежнему важными, вызывающими наибольший интерес у казаков оставались хозяйственные аспекты деятельности власти, но перечень вопросов, интересующих население, значительно расширился.

Для власти также актуальным оставался мониторинг политических настроений казачества, что находило свое отражение в различных сводках, поступающих с мест в губернские и краевые органы управления. В отчетах станичных партийных организаций обзор политического состояния населения станиц стоял на первом месте; отмечалось сохраняющееся недоверие к советской власти, остатки политического бандитизма в казачьих районах. Появляется новый момент в виде фиксирования настроений и поведения реэмигрантов.

Недоверие к советской власти и партии отмечалось, прежде всего, в связи с выборами в местные органы власти. Например, в станице Арженовской Хоперского округа негативное отношениек местной партийной ячейке и исполкому проявлялось в том, что «...население не поднимает руки за кандидата, peкомендуемого ячейкой РКП(б) или исполкомом, если же одного и того же кандидата выставит беспартийный из среды граждан, то тот же самый кандидат пройдет чуть ли не единогласно» [5, л. 53].

В настроениях сельского населения, отражавших отклик на экономические мероприятия власти, на первое место вышел вопрос землеустройства. В казачьих областях этот вопрос оставался достаточно острым с учетом того, что казаки болезненно реагировали на попытки любых изменений этого хозяйственного сектора, в связи с чем в ноябре 1920 г. вышел Декрет ВЦИК и СНК РСФСР «О землепользовании и землеустройстве в бывших казачьих областях». Декрет, по сути, сохранял сложившуюся систему землепользования в казачьих областях, оставляя казакам их надельные земли. Однако в 1922 г. советская власть вернулась к необходимости ре- организации системы землепользования и землеустройства у казаков, начав аграрный передел на юге России.

Восстановление сельского хозяйства, рост запашки, активизация хозяйственной инициативы у казаков и крестьян обострили земельный вопрос в казачьих областях юга России. Для его разрешения и были проведены землеустроительные работы, ключевым моментом которых являлось перераспределение земельных наделов, уменьшение крупных наделов, и за счет этого наделение землей безземельных или малоземельных казаков и крестьян. Одновременно процесс землеустройства должен был разрешить давние проблемы казачьего землепользования, связанного с чересполосицей, длинноземельем, слабой агрономической техникой обработки земли и др., то есть этот процесс мог существенно модернизировать сельское хозяйство.

Для власти вопрос модернизации сельского хозяйства в казачьих районах являлся не только вопросом экономическим, но и политическим, призванным разрушить прежний казачий быт. В «Тезисах о работе в деревне», озвученных в сентябре 1924 г. на Пленуме Царицынского губкома, отмечалось: «Таким образом, старые земельные отношения и первобытные (экстенсивные) формы обработки земли создают (особенно в округах) общественные отношения, трудно поддающиеся революционизированию. Поэтому центр тяжести работы партии должен быть направлен на мероприятия по переустройству сельского хозяйства, в первую очередь в округах» [16, л. 52].

Вместе с тем процесс землеустройства всколыхнул сельское население, в частности казаков, и, как отмечалось в материалах по изучению деревни Царицынского губкома за 1924 г., «казачество очень интересуется землеустроительными и оросительными работами...» [11, л. 43]. Следует отметить и фокусировку внимания на таком моменте, как усиление проявления сословной розни между казаками и иногородними. Если на протяжении 1920-1922 гг. проблема сословной розни практически не отмечалась в материалах советско-партийного руководства, то в 19231924 гг. произошел всплеск проявлений настроений такого рода в казачье-крестьянс- 
кой среде. Так, в материалах из станиц отмечалось, что казаки «... ненавидят всех мужиков, то есть иногородних, и на всех собраниях кричат, что мужикам земли не дать, а пользоваться своими паями, а, если дать, так где-то вдали и указывают на негодную землю...» $[13$, л. 70$] ;$ «...20 июня в период передела земли получилось обострение между казаками и пришлым населением. Зажиточное казачество было за то, чтобы не дать земли крестьянам...» [12, л. 85].

Настроение казачье-крестьянского населения по-прежнему сильно зависело от урожая, обозначавшего относительную хозяйственную стабильность или, напротив, резкое ухудшение жизни в селе. Так, в уже упомянутой станице Арженовской в октябре 1924 г. местная власть отмечала неудовлетворительное настроение населения в связи «с полнейшим недородом» [5, л. 53]. В письмах казаков за границу родственникам слова безысходности и покорности судьбе можно отметить именно в связи с ситуацией засухи и гибели урожая: «Дорогой сыночек... мы этот год собираемся умирать, потому, что голод предстоит еще больше, чем был в 21-22-м годах. Весенний хлеб совсем погиб, а на озимые тоже мало надеи. А налог само собой отдай, хотя заработай, а им выплати...» [10, с. 1011]. Особенно пострадали северные районы бывшей Донской области. В письмах из Хоперского, Усть-Медведицкого, 2-го Донского и Сальского округов отмечается, что «Нонешний год складывается очень неурожайный, так что рожь покосили на корма, а пшеница совсем пропала» (Усть-Медведицкий округ), «Этот год будет очень тяжел для народа. Старого хлеба нет, а новый не родился... Вместо яровых хлебов черные загоны. Что поел суслик, а более пожгло ветром и солнцем. Жара такая, что Сал совсем высох...» (Сальский округ) [9, с. 41]. В других донских округах и на Кубани, где урожай все же был, ситуация сложилась не столь катастрофическая, и в письмах к родным рисуются иные картины и иные заботы являются актуальными: «у нас продукты питания очень дешевы... но беда в том, что полный застой в делах, крестьянин бедный... покупная способность пала... Душит нас полное безденежье» (Кубань), «в этом году в нашем районе урожай трав был пре- красный, хлебов - средний, подсолнуха - хороший... необыкновенно хорош урожай винограда. Ростов живет старой жизнью: масса магазинов, ресторанов, пивных, увеселительных мест. Базары ломятся от продуктов. Цены на продукты довоенные, на фабрично-заводские значительно выше...» (Ростов-на-Дону) $[9$, c. 43$]$.

Общая экономическая стабилизация и политическое успокоение в обществе постепенно выводили на повестку дня и другие вопросы: развитие кооперации («по хуторам Мигулинской станицы вновь возникают кредитные товарищества на прежних местах...»), прикрепление душевого надела, работа мельниц, сокращение студентов и служащих, наличие мануфактуры, возможность наладить быт («по-прежнему ходим раздетыми и босыми... Дорога мануфактура, но особенно дорого кожевенный товар») и др. $[9$, c. $39,40,43]$.

Таким образом, в 1923-1924 гг. вследствие как политико-экономических мероприятий советской власти - прежде всего, проведения политики «лицом к деревне», - так и общего успокоения ситуации в казачьих районах, сокращения проявлений бандитизма в политической и уголовной формах, подъем хозяйства и т. д. создали предпосылки для изменения настроений населения. Оптимизм в настроениях казаков проявлялся не только в их письмах близким за границу, но и был отмечен советской властью. В 1923 г. в документах Царицынского губкома фиксировалось: «Резко отметился перелом казачества и крестьянства в сторону делового сотрудничества с Советской властью и стремление использовать все возможности для развития сельского хозяйства...» [6, с. 49].

Подводя итоги анализа проявлений общественных настроений донского казачества в начале 1920-х гг., можно отметить следующее. Послевоенное состояние казачьего сообщества (1920-1922 гг.) в экономическом плане характеризовалась крайней разрухой и упадком хозяйства. Особенно сильно пострадали от военных событий верхнедонские, северные округа, что отразилось на общественных настроениях, создав ситуацию социальной апатии. Протестные политические настроения казаков в это время практически не вы- 
являлись, хотя и поддержки советской власти со стороны казаков не было. Обескровленное Гражданской войной и репрессиями, донское казачество не оказывало активной поддержки повстанческому движению, что дало повод властям говорить об изменениях в настроениях казачества в сторону поддержки советской власти.

Вместе с тем говорить о такой поддержке в данный период преждевременно. В целом политический негативизм либо, напротив, относительно позитивный настрой казаков проявлялся ситуативно (в зависимости от конкретных действий власти на местах). Наибольшее влияние на настроение казачьего населения оказывало состояние хозяйственного сектора. Разорение казачьих и крестьянских хозяйств войной выводило на первый план необходимость выживания, что сглаживало, приглушало как политический, так и социальносословный антагонизм в казачьих областях.

В 1923-1924 гг. в общественных настроениях казачества происходят изменения, связанные с двумя моментами. Первый - преодоление наиболее тяжелых последствий Гражданской войны и общий подъем хозяйства, второй - начало нового политического курса партии, получившего в казачьих областях наименование «лицом к казачеству». В полной мере позитивное влияние данного курса скажется к 1925 г., когда сложится система социально-политических и экономических мер по вовлечению казачества в советское строительство. Однако в 1923-1924 гг. позитивное влияние этой политики уже начало проявляться.

В целом можно сказать, что в социальном плане настроение казачества стало более оптимистичным, постепенно изживалась апатия. С течением времени казаки переставали ощущать свою отчужденность от социально-политических процессов, что позитивно сказывалось на их отношении к власти.

\section{ПРИМЕЧАНИЯ}

1 Работа выполнена при финансовой поддержке РГНФ. Проект № 16-11-34003 «Социальнополитические настроения донского казачества в период социалистической модернизации 1920 1940-х годов».
2 Политико-экономический обзор Сталинградской области. Источник датирован 1952 годом. В документе не поясняется, каким образом происходило переложение окружного деления на районное.

\section{СПИСОК ЛИТЕРАТУРЫ}

1. Баранов, А. В. Повстанческое движение «бело-зеленых» в казачьих областях юга России (1920-1924 гг.) / А. В. Баранов // Альманах «Белая гвардия». - М. : Посев, 2005. - № 8: Казачество России в Белом движении. - С. 119-129.

2. Бугай, Н. Ф. Обобщающий труд по истории и культуре казачества : (Рец. на кн.: Очерки истории и культуры казачества Юга России : коллектив. моногр. / под ред. Г. Г. Матишова, И. О. Тюменцева; Южный научный центр Российской академии наук; Волгоградский филиал ФГБОУ ВПО «Российская академия народного хозяйства и государственной службы при президенте РФ». - Волгоград : Изд-во Волгогр. филиала ФГБОУ ВПО РАНХиГС, 2014. 624 с.) / Н. Ф. Бугай // Вестник Волгоградского государственного университета. Серия 4, История. Регионоведение. Международные отношения. 2016. - T. 21, № 2. - C. 159-164. - DOI: http://dx.doi.org/ 10.15688/jvolsu4.2016.2.16.

3. Грищенко, А. Н. «Да здравствует власть народная на принципах братства, равенства и свободы»: мятеж К.Т. Вакулина, повстанческая армия Ф. Попова / А. Н. Грищенко // Крестьянский фронт 1918-1922 гг. : сб. ст. и материалов. - М. : АИРО-ХХІ, 2013. - С. 529-549.

4. Грищенко, А. Н. «...Рядовую массу казаков влить в свою армию»: рейд махновской армии на верхний Дон (сентябрь 1920 года) / А. Н. Грищенко // «Атаманщина» и «партизанщина» в Гражданской войне: идеология, военное участие, кадры : сб. ст. и материалов / под ред. А. В. Посадского. - М. : АИРО-ХХІ. -2015. - С. 440-457.

5. Двухмесячный информационный доклад за сентябрь и октябрь месяцы 1924 г. Арженовской станячейки РКП(б) в Хоперский окружной комитет РКП(б), 1924 // Центр документации новейшей истории Волгоградской области (ЦДНИВО). - Ф. 9. Оп. 1. - Д. 332 (неопубликованный).

6. Доклад Губкома РКП(б). Работа на местах, 1923 // ЦДНИВО. - Ф. 1. - Оп. 1. - Д. 102 (неопубликованный).

7. Доклад о работе Хоперского окружного комитета РКП(б) за год. С октября 1924 г. по октябрь 1925 г., 1925 // ЦДНИВО. - Ф. 9. - Оп. 1. - Д. 8 (неопубликованный).

8. Доклад об этапах развития казачества и состояния его в данное время. ОО ОГПУ 31 стрелковой дивизии и Сталинградской губернии, 1941 // Архив Уп- 
равления ФСБ по Волгоградской области (АУФСБ по Волгоградской области). - Ф. 7. - Д. 87. - Л. 1-88 (неопубликованный).

9. Крестная ноша: трагедия казачества. Ч. І. Как научить собаку есть горчицу // Дон. - 1990. - С. 37-58.

10. Крестная ноша: трагедия казачества / сост. В. С. Сидоров. - Ростов н/Д : Гефест, 1994. - Ч. I : Как научить собаку есть горчицу. 1924-1934. - 512 с.

11. Материалы по изучению деревни (Хоперского округа и Царицынского уезда), 1924 // ЦДНИВО. Ф. 1.-Оп. 1. - Д. 220 (неопубликованный).

12. Отчет Арженовского станкома РКП(б) о работе за период с 1.07 по 30.09, 1924 // ЦДНИВО. Ф. 9. - Оп. 1. - Д. 332 (неопубликованный).

13. Отчет Арженовского станкома РКП(б) о работе за период с 1.04 по 30.04, 1925 // ЦДНИВО. Ф. 9. - Оп. 1. - Д. 332 (неопубликованный).

14. Перехов, Я. А. Власть и казачество: поиск согласия (1920-1926 гг.) / Я. А. Перехов. - Ростов н/Д : Гефест, 1997.- 140 с.

15. Политико-экономический обзор Сталинградской области, 1952 // АУФСБ по Волгоградской области. - Ф. 2. - Оп. 18. - Пор. номер 29. - Л. 47109об. (неопубликованный).

16. Протокол № 4 заседания Пленума Царицынского губкома РКП(б) от 27 сентября, 1924 // ЦДНИВО. - Ф. 1. - Оп. 1. - Д. 113 (неопубликованный).

17. Протокол № 4/14 экстренного заседания комитета Хоперской окружной организации РКП(б) и окрисполкома от 23 февраля, 1921 // ЦДНИВО. Ф. 9. - Оп. 1. - Д. 6. - Л. 67 (неопубликованный).

18. Протокол заседания областной партийной конференции от 11 октября, 1920 // Центр документации новейшей истории Ростовской области (ЦДНИРО). Ф. 4. - Оп. 1. - Д. 10 (неопубликованный).

19. Сводка о работе окружных комитетов РКП(б). Настроение населения Хоперского округа, 1919 // ЦДНИВО. - Ф. 9. - Оп. 1. - Д. 2. - Л. 8 (неопубликованный).

20. Скорик, А. П. Донцы в 1920-х годах: очерки истории / А. П. Скорик, Р. Г. Тикиджьян. - Ростов н/Д: Изд-воСКНЦВШЮФУ, 2010. - 244 с.

21. Стенограмма I Донской областной партийной конференции, 1920 // ЦДНИВО. - Ф. 9. - Оп. 1. Д. 2 (неопубликованный).

22. Стенограмма II Донской областной партийной конференции, 1920 // ЦДНИРО. - Ф. 4. - Оп. 1. Д. 8 (неопубликованный).

23. Сухова, О. А. Психология «революционного чина»: к вопросу о мотивации поведения российского крестьянства в годы революции и гражданской войны в России (по материалам Среднего Поволжья) / О. А. Сухова // Падение империи, революция и гражданская война в России / сост. С. М. Исхаков. - М. : Социально-полит. МЫСЛЬ, 2010. - С. 209-225.
24. Циркулярное письмо Донского комитета окружным комитетам компартии, 1920 // ЦДНИРО. Ф. 4. - Оп. 1. - Д. 45 (неопубликованный).

25. Ященко, В. Г. Антибольшевистское повстанчество в Нижнем Поволжье и на Среднем Дону: 1918-1923 / В. Г. Ященко. - М. : ЛИБРОКОМ, 2008. $152 \mathrm{c}$.

\section{REFERENCES}

1. Baranov A.V. Povstancheskoe dvizhenie «belo-zelenykh» v kazachyikh oblastyakh yuga Rossii (1920-1924 gg.) [The Insurgent "White-Green" Movement in the Cossack Areas of the South of Russia (1920-1924)]. Almanakh «Belaya gvardiya». Vyp. 8. Kazachestvo Rossii v Belom dvizhenii [Belaya Gvardiya Almanac. Iss. 8. The Cossacks of Russia in the White Movement]. Moscow, Posev Publ., 2005, pp. 119-129.

2. Bugay N.F. Obobshchayushchiy trud po istorii i kulture kazachestva (Retsenziya na knigu: Ocherki istorii i kultury kazachestva Yuga Rossii: kollektivnaya monografiya [The Generalizing Work on History and Culture of the Cossacks. Book Review: Matishov G.G., Tyumentsev I.O., eds. Essays on History and Culture of the Cossacks of the Southern Russia: Collective Monograph. Volgograd, Izd-vo RANKhiGS, 2014. 624 p.]. Vestnik Volgogradskogo gosudarstvennogo universiteta. Seriya 4, Istoriya. Regionovedenie. Mezhdunarodnye otnosheniya [Science Journal of Volgograd State University. History. Area Studies. International Relations], 2016, vol. 21, no. 2, pp. 159-164.

3. Grishchenko A.N. «Da zdravstvuet vlast narodnaya na printsipakh bratstva, ravenstva i svobody»: myatezh K.T. Vakulina, povstancheskaya armiya F. Popova ["Long live Public Authority on the Principles of Brotherhood, Equality and Freedom": K.T. Vakulin's Riot, F. Popov's Insurgent Army]. Krestyanskiy front 1918-1922 gg.: sb. st. i materialov [Peasantry Front of 1918-1922: Collected Articles and Materials]. Moscow, AIRO-XXI Publ., 2013, pp. 529-549.

4. Grishchenko A.N. «...Ryadovuyu massu kazakov vlit v svoyu armiyu»: reyd makhnovskoy armii na verkhniy Don (sentyabr 1920 goda) [“...To Replenish the Army with the Ordinary Mass of Cossacks": Raid of Makhnov's Army to the Upper Don (September, 1920)]. Posadskiy A.V., ed. "Atamanshchina» $i$ "partizanshchina» v Grazhdanskoy voyne: ideologiya, voennoe uchastie, kadry: sb. st. i materialov ["Atamanship" and "Partisanship" in the Civil War: Ideology, Military Participation, Staff]. Moscow, AIROXXIPubl., 2015, pp. 440-457.

5. Dvukhmesyachnyy informatsionnyy doklad za sentyabr i oktyabr mesyatsy $1924 \mathrm{~g}$. Arzhenovskoy 
stanyacheyki RKP(b) v Khoperskiy okruzhnoy komitet RKP(b), 1924 [The Two-Month Information Report for September and October, 1924 of the Arzhenovsky Cossack Village of RCP(b) to the Khoper District Committee of RCP(b), 1924]. Tsentr dokumentatsii noveyshey istorii Volgogradskoy oblasti [Center of Documentation of the ContemporaryHistory of the Volgograd Region], F. 9, Op. 1, D. 332. (unpublished source).

6. Doklad Gubkoma RKP(b). Rabota na mestakh, 1923 [Report of Provincial Committee of RCP(b). Field Activities, 1923]. Tsentr dokumentatsii noveyshey istorii Volgogradskoy oblasti [Center of Documentation of the Contemporary History of the Volgograd Region], F. 1, Op. 1, D. 102. (unpublished source).

7. Doklad o rabote Khoperskogo okruzhnogo komiteta RKP(b) za god. S oktyabrya 1924 g. po oktyabr 1925 g., 1925 [The Report on Work of the Khoper District Committee of RCP(b) for a Year. From October, 1924 to October, 1925, 1925]. Tsentr dokumentatsii noveyshey istorii Volgogradskoy oblasti [Center of Documentation of the Contemporary History of the Volgograd Region], F. 9, Op. 1, D. 8. (unpublished source).

8. Doklad ob etapakh razvitiya kazachestva $\mathrm{i}$ sostoyaniya ego $\mathrm{v}$ dannoe vremya. OO OGPU 31 strelkovoy divizii i Stalingradskoy gubernii, 1941 [Report on Stages of the Cossacks Development and Their State at Present. Counterintelligence of the 31st Rifle Division and the Stalingrad Province, 1941]. Arkhiv Upravleniya FSB po Volgogradskoy oblasti [Archive of FSS Management in the Volgograd Region], F. 7, D. 87, L. 1-88 (unpublished source).

9. Krestnaya nosha: tragediya kazachestva. Chast I. Kak nauchit sobaku est gorchitsu [Christ Burden: Tragedy of the Cossacks. Part I. How to Teach a Dog Eat Mustard]. Don, 1990, pp. 37-58.

10. Sidorov V.S. Krestnaya nosha: tragediya kazachestva. Ch. I: Kak nauchit sobaku est gorchitsu. 1924-1934 [Christ Burden: Tragedy of the Cossacks. Part I. How to Teach a Dog Eat Mustard. 1924-1934]. Rostov-on-Don, Gefest Publ., 1994. 512 p.

11. Materialy po izucheniyu derevni (Khoperskogo okruga i Tsaritsynskogo uezda), 1924 [Materials on Studying the Village of the Khoper District and the Tsaritsyno County, 1924]. Tsentr dokumentatsii noveyshey istorii Volgogradskoy oblasti [Center of Documentation of the Contemporary History of the Volgograd Region], F. 1, Op. 1, D. 220. (unpublished source).

12. Otchet Arzhenovskogo stankoma RKP(b) o rabote za period s 1.07 po 30.09, 1924 [The Report of the Arzhenovsky Cossack Village Committee of RCP(b) on Work from July 1, 1924 to September 30, 1924]. Tsentr dokumentatsii noveyshey istorii Volgogradskoy oblasti [Center of Documentation of the Contemporary History of the Volgograd Region], F. 9, Op. 1, D. 332. (unpublished source).
13. Otchet Arzhenovskogo stankoma RKP(b) o rabote za period s 1.04 po 30.04, 1925 [The Report of the Arzhenovsky Cossack Village Committee of RCP(b) on Work from April 1, 1925 to April 30, 1925]. Tsentr dokumentatsii noveyshey istorii Volgogradskoy oblasti [Center of Documentation of the Contemporary History of the Volgograd Region], F. 9, Op. 1, D. 332. (unpublished source).

14. Perekhov Ya.A. Vlast i kazachestvo: poisk soglasiya (1920-1926 gg.) [Power and Cossacks: Search of Consent (1920-1926)]. Rostov-on-Don, Gefest Publ., 1997. 140 p.

15. Politiko-ekonomicheskiy obzor Stalingradskoy oblasti, 1952 [Political and Economic Review of the Stalingrad Region, 1952]. Arkhiv Upravleniya FSB po Volgogradskoy oblasti [Archive of FSS Management in the Volgograd Region], F. 2, Op. 18, no. 29. (unpublished source).

16. Protokol № 4 zasedaniya Plenuma Tsaritsynskogo gubkoma RKP(b) ot 27 sentyabrya, 1924 [The Protocol no. 4 of a Meeting of the Plenum of the Tsaritsyn Provincial Committee of RCP(b) of September 27, 1924]. Tsentr dokumentatsii noveyshey istorii Volgogradskoy oblasti [Center of Documentation of the Contemporary History of the Volgograd Region], F. 1, Op. 1, D. 113. (unpublished source).

17. Protokol № 4/14 ekstrennogo zasedaniya komiteta Khoperskoy okruzhnoy organizatsii RKP(b) i okrispolkoma ot 23 fevralya, 1921 [Protocol no. 4/14 of a Special Session of Committee of the Khoper District Organization RCP(b) and District Executive Committee of February 23, 1921]. Tsentr dokumentatsii noveyshey istorii Volgogradskoy oblasti [Center of Documentation of the Contemporary History of the Volgograd Region], F. 9, Op. 1, D. 2.

18. Protokol zasedaniya oblastnoy partiynoy konferentsii ot 11 oktyabrya, 1920 [The Minutes of a Regional Party Conference of October 11, 1920]. Tsentr dokumentatsii noveyshey istorii Volgogradskoy oblasti [Center of Documentation of the Contemporary History of the Volgograd Region], F. 4, Op. 1, D. 10.

19. Svodka o rabote okruzhnykh komitetov RKP(b). Nastroenie naseleniya Khoperskogo okruga, 1919 [The Report about Work of District Committees of RCP(b). Mood of the Population of the Khoper District, 1919]. Tsentr dokumentatsii noveyshey istorii Volgogradskoy oblasti [Center of Documentation of the Contemporary History of the Volgograd Region], F. 9, Op. 1, D. 2. (unpublished source).

20. Skorik A.P., Tikidzhyan R.G. Dontsy v 1920kh godakh: ocherki istorii [Don Citizens in the 1920s: History Sketches]. Rostov-on-Don, Izd-vo SKNTs VSh YuFU, 2010. 244 p.

21. Stenogramma I Donskoy oblastnoy partiynoy konferentsii, 1920 [Shorthand Report of the I Don 
Regional Party Conference, 1920]. Tsentr dokumentatsii noveyshey istorii Volgogradskoy oblasti [Center of Documentation of the Contemporary History of the Volgograd Region], F. 9, Op. 1, D. 2. (unpublished source).

22. Stenogramma II Donskoy oblastnoy partiynoy konferentsii, 1920 [Shorthand Report of the II Don Regional Party Conference, 1920]. Tsentr dokumentatsii noveyshey istorii Rostovskoy oblasti [Center of Documentation of the Contemporary History of the Rostov Region], F. 4, Op. 1, D. 8. (unpublished source).

23. Sukhova O.A. Psikhologiya «revolyutsionnogo china»: $\mathrm{k}$ voprosu o motivatsii povedeniya rossiyskogo krestyanstva $\mathrm{v}$ gody revolyutsii i grazhdanskoy voyny v Rossii (po materialam Srednego Povolzhya) [Psychology of a "Revolutionary Rank": on Motivation of the Russian Peasantry during the Revolution and the
Civil War in Russia (on Materials of the Central Volga Region)]. Ishakov S.M., ed. Padenie imperii, revolyutsiya $i$ grazhdanskaya voyna $v$ Rossii [Fall of the Empire, Revolution and Civil War in Russia]. Moscow, Sotsialno-politicheskaya mysl Publ., 2010, pp. 209-225.

24. Tsirkulyarnoe pismo Donskogo komiteta okruzhnym komitetam kompartii, 1920 [Circular Letter of the Don Committee to District Committees of the Communist Party, 1920]. Tsentr dokumentatsii noveyshey istorii Rostovskoy oblasti [Center of Documentation of the Contemporary History of the Rostov Region], F. 4, Op. 1, D. 45. (unpublished source).

25. Yashchenko V.G. Antibolshevistskoe povstanchestvo $v$ Nizhnem Povolzhye $i$ na Srednem Donu: 1918-1923 [Anti-Bolshevist Rebellion in the Lower Volga Region and on Central Don: 1918-1923]. Moscow, LIBROKOM Publ., 2008. 152 p.

\section{Information about the Author}

Olga V. Rvacheva, Candidate of Sciences (History), Associate Professor, Department of Public Administration and Political Science, Russian Presidential Academy of National Economy and Public Administration (Volgograd Branch), Gagarina St., 8, 400131 Volgograd, Russian Federation, olgarvacheva@mail.ru, http://orcid.org/0000-0002-5039-4744.

\section{Информация об авторе}

Ольга Владимировна Рвачева, кандидат исторических наук, доцент кафедры государственного управления и политологии, Волгоградский филиал Российской академии народного хозяйства и государственной службы, ул. Гагарина, 8, 400131 г. Волгоград, Российская Федерация, olgarvacheva@mail.ru, http://orcid.org/0000-0002-5039-4744. 